\title{
Antibacterial activities of fungal endophytes associated with the Philippine endemic tree, Canarium ovatum
}

\author{
Torres JMO ${ }^{1}$ and dela Cruz TEE $^{2}$
}

\author{
${ }^{I}$ Department of Biology, School of Science and Engineering, Ateneo de Manila University, Katipunan Ave., Quezon \\ City, Philippines \\ ${ }^{2}$ Fungal Biodiversity and Systematics Group, Research Center for the Natural and Applied Sciences, University of \\ Santo Tomas, España Blvd., Manila, Philippines Email: tedelacruz@mnl.ust.edu.ph / thomasdelacruz@yahoo.com
}

Torres JMO, dela Cruz TEE 2015 - Antibacterial activities of fungal endophytes associated with the Philippine endemic tree, Canarium ovatum. Mycosphere 6(3), 266-273, Doi 10.5943/mycosphere/6/3/4

\begin{abstract}
Fungal endophytes are sources of novel bioactive metabolites. Studies worldwide are tapping unique and interesting flora in search for endophytes that produce these metabolites. In the Philippines, there are more than 6,000 endemic plant species, one of which is the local "pili" tree (Canarium ovatum Engl.). This study investigates the occurrence of these fungal endophytes in $C$. ovatum and their potential in producing antibacterial metabolites. Results showed the presence of fungal endophytes in C. ovatum and that the "pili" tree is a good host for fungal endophytes regardless of geographical location. Results of the antibacterial assay showed that $10 \mathrm{mg} / \mathrm{mL}$ of the Colletotrichum sp. PFE31 crude extract exhibited broad-spectrum antibacterial activity against representative Gram-positive, Gram-negative, and spore-forming bacilli.
\end{abstract}

Key words - bioactivity - fungal metabolites - pili tree - Sorsogon

\section{Introduction}

Endophytic fungi or fungal endophytes are microfungi that colonize and reside within healthy plant tissues without causing visible negative symptoms (Hyde \& Soytong 2008). These endophytes are present in practically all plant species studied to date (Strobel \& Daisy 2003, Huang et al. 2009) and their ubiquity is so extensive that it is believed that each individual plant on earth hosts one or more endophytes (Strobel \& Daisy 2003). Nonetheless, this belief is not surprising when we consider the fact that these fungi confer different kinds of plant defenses, i.e. decreased herbivory and increased resistance against pathogens and pests (Arnold et al. 2003, Albrectsen et al. 2010). They also have been found to enhance the plant growth of their host (Hallmann \& Sikora 1996). Despite their expected enormous biodiversity, researchers have only explored in detail the endophytic communities of a relatively limited number of plants (Hyde \& Soytong 2008), most of which involved studies about fungal endophytes associated with temperate grasses and, to a lesser extent, tropical trees and flowering plants (de Errasti et al. 2010, Tao et al. 2012).

The Philippine archipelago, considered as one of the megabiodiverse hotspots in the world, harbors more than 9,000 species of plants, over 6,000 of which are endemic (Conservation International 2007). Amidst the country's floral diversity, there are very limited studies regarding the associated mycoflora, especially on endophytic fungi. Studies on fungal endophytes from Philippine plants mostly involve those associated with plants with economic value, i.e. Pandanus 
amaryllifolius (Bungihan et al. 2010, 2011, 2013a, 2013b), Musa spp. (Dagamac et al. 2008), Ipomea batatas (Hipol 2012), Ficus sp. (Solis et al. 2014). One endemic plant which has not yet been fully explored for endophytic fungal communities is the Philippine "pili" tree (Canarium ovatum). This particular tree species is the most important nut-producing species of Canarium present in the country. Pili trees have a geographic distribution that remains limited to areas relatively close to its center of origin (Coronel 1996). Furthermore, although its existing gene pool does not seem to be under immediate threat, the total pili tree population is rapidly and continuously dwindling (Coronel 1996). Therefore, it is imperative that the mycofloral communities of this species be documented and explored for possible biotechnological applications.

Traditionally, microorganisms that were investigated for novel therapeutic agents were isolated from soil. However, scientists have recently shifted their attention to less investigated ecological niches. This has led to greater emphasis on the exploration of fungi associated with higher plants as possible sources of novel biologically-active compounds. The search for new candidate drugs is still pressing since adequate effective treatment against emerging and reemerging diseases are urgently needed (Aly et al. 2011). Thus, this study aims to determine if the local pili tree is a viable host to fungal endophytes and if these fungal endophytes have the potential to produce secondary metabolites that are of medical interest.

\section{Materials \& Methods \\ Sample Collection}

Healthy leaves and stems were collected from mature Pili trees (Canarium ovatum) found in Guinlajon, Gubat, Juban, and Bulusan Volcano National Park in Sorsogon, Philippines. The collection site in Guinlajon was a local farm, in Gubat was a forest patch near residential areas, in Juban was a pili nursery station, and in Bulusan was a protected national park around a volcano. Five to ten pieces of each plant part per site were gathered and placed in clean polyethylene bags, and then transported to the laboratory for processing. Samples were stored on ice and processed in the laboratory within 48 hours.

\section{Isolation and identification of fungal endophytes}

All samples were rid of debris by rinsing with running tap water. A flame-sterilized onehole puncher and scalpel were then used to draw thirty leaf explants $(6 \mathrm{~mm}$ in diameter) and stem explants, respectively, from the samples collected from each sampling site. Afterwards, all explants were subjected to surface-sterilization following the protocol of Torres \& dela Cruz (2013). Explants were washed in $0.525 \% \mathrm{NaOCl}$ solution (commercially-available bleach solution) for two minutes, and then, were washed twice in sterile distilled water. The surface-sterilized explants were then transferred in plates containing Malt Extract Agar (MEA) amended with streptomycin (300 $\mathrm{mg} / \mathrm{L}$ ) to prevent bacterial growth. Six explants were transferred to each plate, amounting to a total of five plates per plant part per each sampled tree. All plates were incubated at room temperature for up to two weeks, and were observed for growth every two days. Emerging mycelia from the edge of the explants were subcultured in freshly prepared MEA plates to obtain pure cultures. After obtaining pure cultures, colonization rate for each substrate for each site was computed using the formula: number of explants colonized by at least one fungus / total number of explants $\mathrm{x} 100$. Stock cultures were maintained in MEA slants and stored at $4{ }^{\circ} \mathrm{C}$. Identification of the isolated fungal endophytes was done following comparison of their morphocultural characters with published literature.

\section{Production and extraction of fungal metabolites}

Fifteen selected fungal isolates were subjected to liquid surface fermentation for the production of secondary metabolites. Flasks containing $100 \mathrm{~mL}$ Malt Extract Broth (MEB) were inoculated with eight-day old spore and mycelial suspensions $\left(\sim 10^{5}\right.$ spores $\left./ \mathrm{mL}\right)$ of the endophytic fungi. All flasks were incubated for two weeks at room temperature under stationary conditions. 
After incubation, metabolites from the broth culture were extracted using ethyl acetate (EtOAc) extraction. Ethyl acetate $(150 \mathrm{~mL})$ was added to the broth culture and the formed mycelial mat was manually macerated. Then, the broth was mixed for two hours at $100 \mathrm{rpm}$ and then left to soak overnight. After 24 hours, the EtOAc extract was separated from the broth using a separatory funnel. The organic layer was then concentrated in vacuo and the resulting mixture was dried overnight. The dried extracts were weighed and then used as the crude metabolites for the antibacterial assay.

\section{Assay for Antibacterial Activities}

Test Bacteria. The test bacteria used in this study were Staphylococcus aureus, Escherichia coli, Serratia marcescens, Micrococcus luteus, Bacillus subtilis, and B. megaterium. All bacterial strains were obtained from the University of Santo Tomas - Collection of Microbial Strains (USTCMS). These were maintained in Nutrient Agar slants and stored at $4^{\circ} \mathrm{C}$.

Paper Disk Diffusion Assay. Bacterial suspensions were prepared from 24-hour old cultures of the test bacteria. All bacterial suspensions were standardized to contain approximately $1.5 \times 10^{8}$ cells/mL based on 0.5 McFarland Standard. The bacteria were then seeded on prepared Mueller Hinton Agar (MHA) plates. The dried crude extracts were re-suspended in methanol-acetone (1:1) to a final concentration of $10 \mathrm{mg} / \mathrm{mL}$. Paper discs $(6 \mathrm{~mm})$ were loaded with $30 \mu \mathrm{L}$ of each of the extracts. The discs were briefly dried prior to transfer to the MHA plates. Duplicate plates were prepared for each test bacteria per each extract. All plates were incubated for 24 hours and then the resulting zones of inhibition were measured and recorded. Negative and positive controls containing only methanol-acetone $(1: 1)$ and $10 \mathrm{mg} / \mathrm{mL}$ streptomycin, respectively, were included. Results were obtained by measuring the zones of inhibition (ZOI) around the paper discs. These measurements were interpreted according to the following categories (Quinto \& Santos 2005): >19 $\mathrm{mm}$ ZOI (very active), $14-19 \mathrm{~mm}$ ZOI (active), $10-13 \mathrm{~mm}$ ZOI (partially active), and $<10 \mathrm{~mm}$ ZOI (inactive).

\section{Results}

Across four collection sites, a total of 141 fungal endophytes were isolated and maintained. These isolates were classified as belonging to more than 18 genera (Table 1). Several species were not identified as they remained sterile in culture even with prolonged incubation. Several genera, such as Acremonium, Alternaria, Chaetomium, Colletotrichum, Phomopsis, and Rhizoctonia, were isolated in high frequency and abundance (Table 1).

Table 1 Genera of fungal endophytes isolated from Canarium ovatum.

\begin{tabular}{|c|c|c|c|c|}
\hline \multirow[b]{2}{*}{ Fungal Genera } & \multicolumn{4}{|c|}{ Study Sites } \\
\hline & Juban & Guinlajon & Gubat & Mt. Bulusan \\
\hline Acremonium & + & + & + & + \\
\hline Alternaria & + & + & + & + \\
\hline Aureobasidium & ni & ni & + & ni \\
\hline Chaetomium & + & + & + & + \\
\hline Colletotrichum & + & + & + & + \\
\hline Coprinus & ni & ni & ni & + \\
\hline Culvularia & + & + & + & ni \\
\hline Fusarium & + & + & ni & ni \\
\hline Geotrichum & + & ni & ni & ni \\
\hline Guignardia & ni & ni & + & ni \\
\hline Myrothecium & + & + & + & + \\
\hline Nigrospora & ni & ni & ni & + \\
\hline Paecilomyces & + & + & ni & + \\
\hline Pestalotiopsis & + & + & ni & + \\
\hline Phialophora & + & ni & ni & ni \\
\hline Phoma & + & + & + & ni \\
\hline Phomopsis & + & + & + & + \\
\hline Rhizoctonia & + & + & + & + \\
\hline Mycelia sterila & + & + & + & + \\
\hline
\end{tabular}


Canarium ovatum is a Philippine endemic tree which has not been fully studied for fungal mycoflora. In this study, results showed that Canarium ovatum is a good source of fungal endophytes having colonization rates of $55 \%$ or more for the tested plant parts (Fig. 1). Looking at the colonization patterns between leaf and stem substrates, stem substrates harbor more endophyte communities as reflected by colonization rates or no less than $78 \%$ in all collection sites (Fig. 1). Across collection sites, it is only in Mt. Bulusan samples where all plated substrates were found to be colonized by at least one endophyte (Fig. 1).

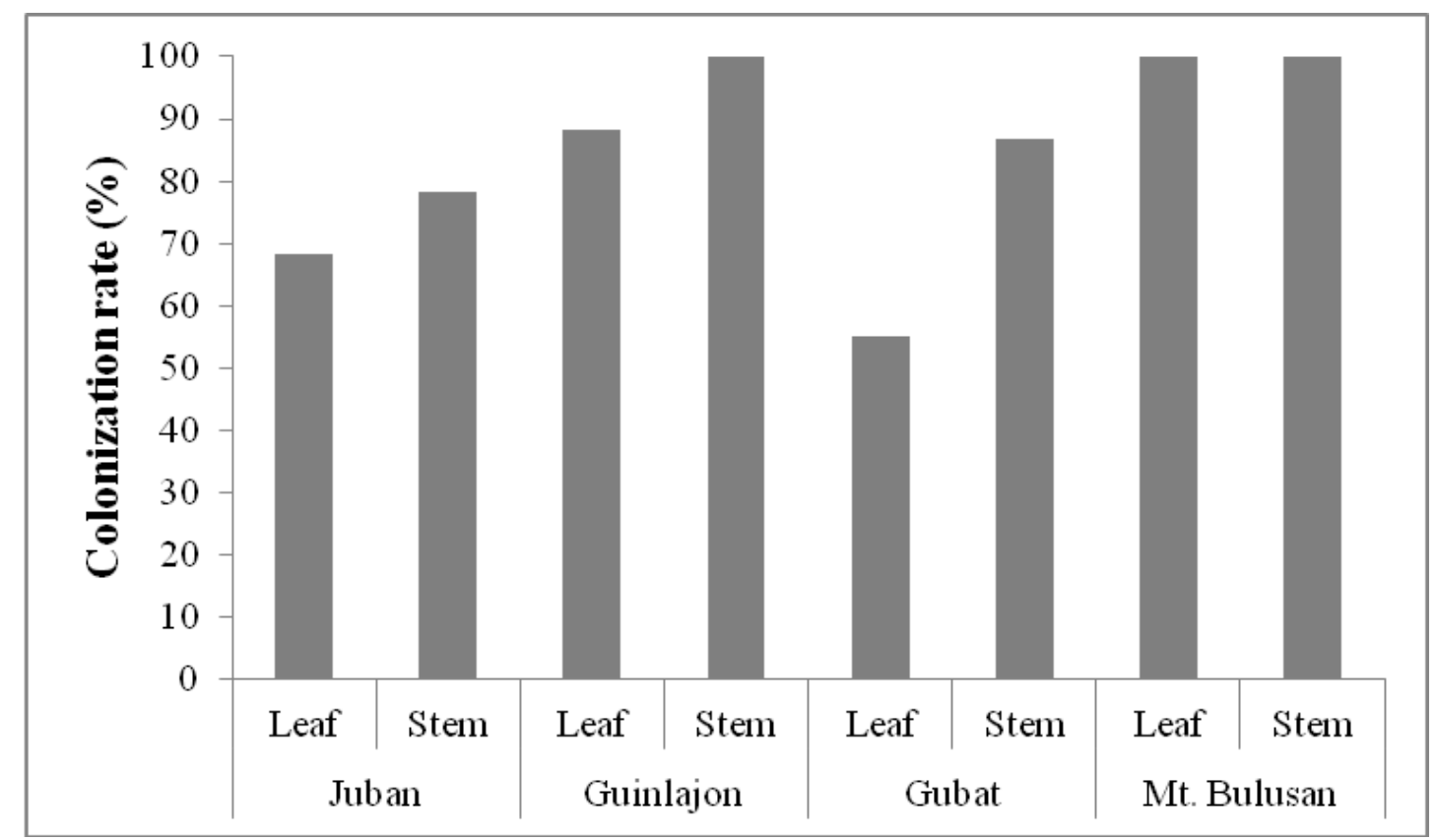

Fig. 1 - Colonization rates of fungal endophytes on C. ovatum leaf and stem explants across collection sites.

The activity profile of the pili fungal endophytes (PFE) crude extracts against the test bacteria is shown in Table 2. Results showed that 12 of the 15 PFE crude extracts exhibited inhibitory activity against at least one of the test bacteria (Table 2). Two of the three PFE isolates that did not exhibit activity to any test bacteria belong to the genus Chaetomium. Conversely, Colletotrichum isolates both showed activity against a wide range of test bacteria (Table 2). In terms of effectiveness, the fungal crude extracts were most effective against the common bacteria $S$. aureus and E. coli (Fig. 2). In contrast, only a few crude extracts were observed to be effective against spore-forming bacteria (Fig. 2).

\section{Discussion}

It is widely suggested that virtually all individual plants in natural ecosystems form an intimate symbiotic relationship with one or more types of fungi, i.e. mycorrhizae or endophytes (Petrini 1986). These mycosymbionts have an immense impact on plant ecology, fitness, and evolution (Clay \& Holah 1999, Brundrett 2004), not only shaping plant communities but also affecting their associated organisms (e.g. nematodes and insects) (Omacini et al. 2001).

Endophytes, unlike mycorrhizae, colonize and reside entirely within the internal tissues of plant parts such as roots, stems, and leaves. Most studies on endophytes are focused on the determination of their diversity in different plant microhabitats. However, the current standard procedure for isolating fungal endophytes only accounts for non-fastidious endophytes. The obligate biotrophs are yet to be routinely cultured, thus, there is an enormous underestimation of their true diversity. Fortunately, molecular techniques can be applied to detect the presence of endophytes in plant tissues (Sun \& Guo 2012). 
Table 2 Results of the paper disk diffusion assay against six test bacteria.

\begin{tabular}{|c|c|c|c|c|c|c|}
\hline \multirow[b]{2}{*}{ PFE crude extract } & \multicolumn{2}{|c|}{$\begin{array}{c}\text { Gram-positive } \\
\text { cocci }\end{array}$} & \multicolumn{2}{|c|}{$\begin{array}{c}\text { Gram-negative } \\
\text { rods }\end{array}$} & \multicolumn{2}{|c|}{$\begin{array}{l}\text { Gram-positive } \\
\text { spore-formers }\end{array}$} \\
\hline & $\begin{array}{c}\widetilde{3} \\
0 \\
0 \\
\vdots \\
\vdots \\
\dot{3}\end{array}$ & $\begin{array}{l}\hat{a} \\
\stackrel{\Xi}{\Xi} \\
\stackrel{\Xi}{\Sigma} \\
\dot{z}\end{array}$ & $\begin{array}{l}\ddot{\tilde{0}} \\
\dot{0}\end{array}$ & 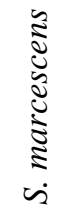 & 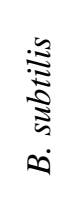 & 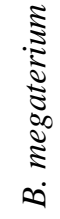 \\
\hline Acremonium sp. PFE21 & $++^{\mathrm{a}}$ & + & ++ & + & ++ & - \\
\hline Acremonium sp. PFE37 & + & ++ & + & + & - & - \\
\hline Alternaria sp. PFE15 & + & ++ & + & - & - & - \\
\hline Chaetomium sp. PFE11 & - & - & - & - & - & - \\
\hline Chaetomium sp. PFE14 & - & - & - & - & - & - \\
\hline Colletotrichum sp. PFE29 & + & + & + & - & - & + \\
\hline Colletotrichum sp. PFE31 & + & ++ & ++ & ++ & + & ++ \\
\hline Geotrichum sp. PFE34 & + & + & + & - & - & - \\
\hline Myrothecium sp. PFE16 & + & - & + & - & - & - \\
\hline Nigrospora sp. PFE19 & - & - & + & ++ & - & - \\
\hline Pestalotiopsis sp. PFE17 & + & + & - & ++ & - & ++ \\
\hline Pestalotiopsis sp. PFE32 & ++ & + & - & - & - & - \\
\hline Phomopsis sp. PFE20 & + & + & + & + & - & - \\
\hline Phomopsis sp. PFE26 & - & + & + & - & - & ++ \\
\hline Rhizoctonia sp. PFE13 & - & - & - & - & - & - \\
\hline
\end{tabular}

$(-)$ = inactive, $<10 \mathrm{~mm} \mathrm{ZOI}$

$(++)=$ active, $14-19 \mathrm{~mm}$ ZOI
$(+)=$ partially active, $10-13 \mathrm{~mm} \mathrm{ZOI}$

$(+++)=$ very active, $>19 \mathrm{~mm} \mathrm{ZOI}$

In this study, standard isolation techniques yielded a total of 141 fungal isolates belonging to at least 18 genera, several of which were constantly isolated regardless of plant part or collection site (Table 1). The colonization rates for each collection site and plant part showed that Canarium ovatum is a very good host of fungal endophytes (Fig. 1). Several tropical plants, such as Guarea guidonia (95\%), Centella asiatica (78\%), Hevea brasiliensis (72\%), and Amomum siamese (83\%), also exhibited high endophyte colonization rates which indicates that tropical plants are excellent substrates for these organisms (Bussaban et al. 2001, Gamboa \& Bayman 2001, Rakotoniriana et al. 2008, Gazis \& Chaverri 2010). Still, it is not uncommon for some tropical plants to have low colonization rates. The Thai wild banana (Musa acuminata) and the Indian neem tree (Azadirachta indica) are good examples of this, having rates of colonization of as low as $41.7 \%$ and $31.5 \%$, respectively (Photita et al. 2001, Verma et al. 2007). It is also worth mentioning that the explants from Gubat (Fig. 1) were obtained from plant seedlings ( 2-week old) and may have contributed to the relatively low colonization rates observed from these samples, particularly for the leaf samples. Despite this, however, it is interesting that note that they still have higher colonization rates compared to a number of temperate plants (Huang et al. 2008). The pili has a relatively limited geographical range of distribution and their believed origin is found in the virgin forests surrounding Mt. Bulusan, where very old pili trees can still be found today (Coronel 1996). Coincidentally, all samples collected from the said locale provided excellent substrates for endophytic fungi (Fig. 1). It is not hard to conceive that the undisturbed nature of the locale was instrumental in providing an excellent niche for the fungi.

About $51 \%$ of biologically active substances that were isolated from endophytic fungi were previously unknown (Firakova et al. 2007). This highlights the vast potential of endophytic fungi as "factories" of bioactive metabolites. In this study, fifteen selected isolates were tested for bioactive secondary metabolites through the paper disc diffusion antibacterial assay. Results showed that $80 \%$ of the fungal crude extracts exhibited antibacterial activity against at least one of the six test bacteria (Table 2). None, however, were found to be very active or is comparable with the 


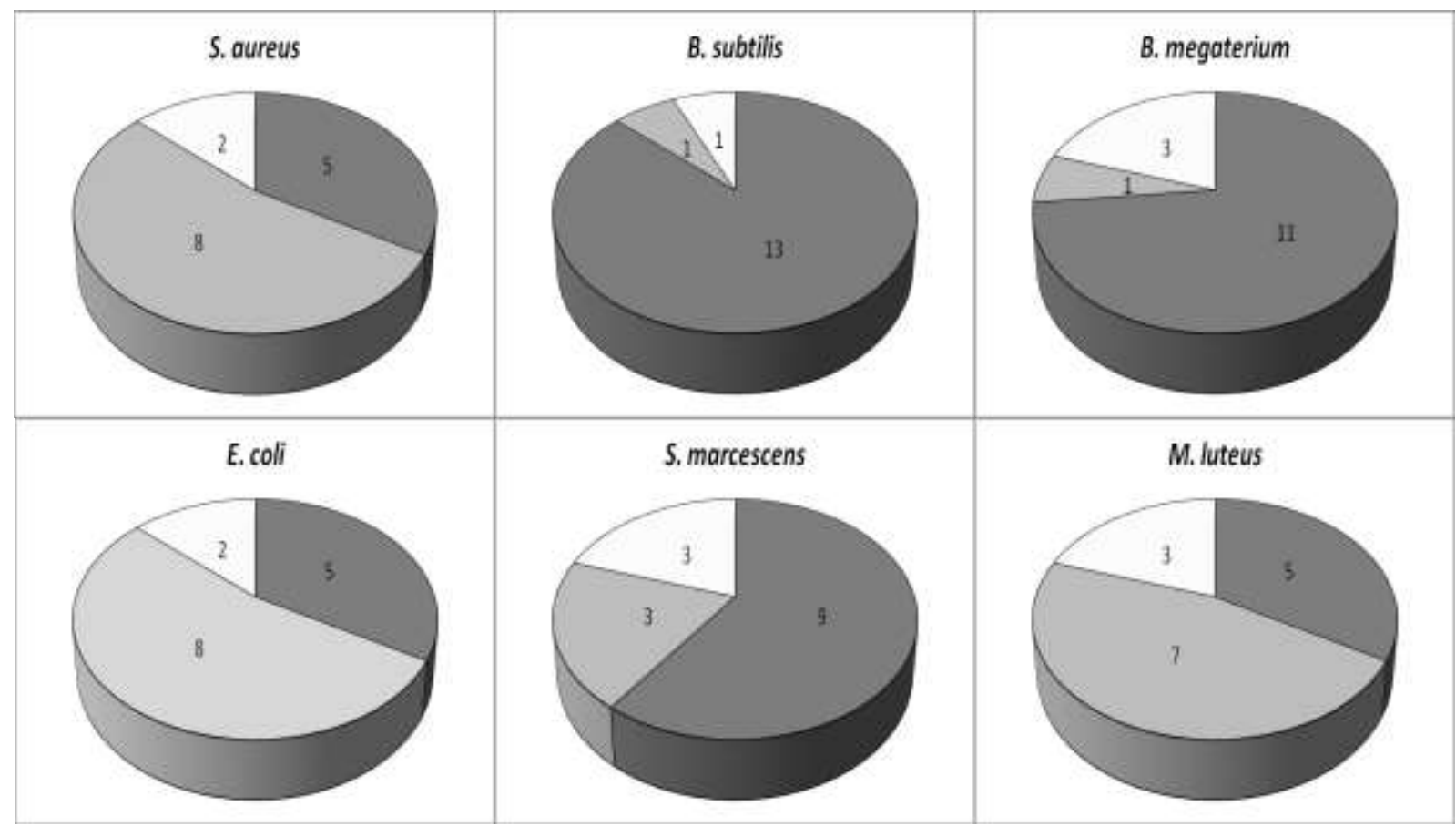

Fig. 2 - Percentage of crude extracts having active (white), partially active (light gray) and inactive (dark gray) inhibition against the test bacteria. Numbers within each chart indicate the number of extracts.

streptomycin control. Several PFE crude extracts (10) exhibited activity against the Gram-positive $S$. aureus and M. luteus, however, they were considerably less effective with the similarly Grampositive spore-forming Bacillus species (Fig. 2; Table 2). Among the fungal species, isolates of Chaetomium exhibited no activity against any of the test bacteria (Table 2). On the other hand, both isolates of Acremonium showed promising potential to inhibit both Gram-positive and Gramnegative pathogens, with the exception of spore-formers (Table 2). Furthermore, both Colletotrichum isolates also exhibited different activities, most notable Colletotrichum sp. PFE31 which was able to inhibit the growth of all test bacteria (Table 2). Despite being derived from the same plant host, differences in the antibacterial activity profile between the two Pestalotiopsis and Phomopsis isolates were observed (Table 2). Differences among the production of bioactive metabolites by endophytes of the same species have been previously noted to be influenced by differences in host plant, season, geographical location, and locale environment (Selim et al. 2011). This study suggests that differences may also occur among same endophytic species found in the same host plant located in very similar locales that are experiencing the same seasonal variations. It is likely that, more than the external factors mentioned, the individual characteristics of the host plant more greatly affect the resulting bioactive metabolites that the endophyte produces. This concurs with the proposition that some endophytes have developed a system that allowed genetic transfer between themselves and their host (Firakova et al. 2007, Selim et al. 2011). It is possibly because of this unique interaction between two eukaryotes that endophytic fungi remain an interesting group of organisms to search for novel bioactive metabolites with potential use in different fields including medicine.

In conclusion, the leaves and stems of the endemic Philippine pili tree, as expected from a tropical plant, were found to be good substrates for endophytic fungi. The fungal crude extracts generally exhibited limited effect on representative spore-forming bacteria. Nevertheless, Colletotrichum sp. PFE31 was observed to have broad-spectrum antibacterial activity against representative Gram-positive and Gram-negative bacteria. Considering the versatility of the metabolites against a broad range of organisms, it is recommended that subsequent purification be done to enhance the activities of the fungal secondary metabolites. 


\section{Acknowledgements}

The authors would like to extend their gratitude to Prof. Dr. Walter Gams and the Studienstiftung Mykologie for providing the research grant for this project and to Mr. Narciso Cayetano, Provincial Agricultural Office, Province of Sorsogon for his technical assistance during the collection of our specimens.

\section{References}

Albrectsen BR, Bjorken L, Varad A, Hagner A, Wedin M, Karlsson J, Jansson S. 2010 Endophytic fungi in European aspen (Populus tremula) leaves - diversity, detection, and a suggested correlation with herbivory resistance. Fungal Diversity 41(1), 17-28.

Aly AH, Debbab A. Proksch P. 2011 - Fifty years of drug discovery from fungi. Fungal Diversity 50 (1), 3-19.

Arnold AE, Mejia LC, Kyllo D, Rojas EI, Maynard Z, Robbins N, Herre EA. 2003 - Fungal endophytes limit pathogen damage in a tropical tree. Proceedings of the National Academy of Sciences 100(26), 15649-15654.

Brundrett M. 2004 - Diversity and classification of mycorrhizal associations. Biological Reviews 79(3), 473-495.

Bungihan ME, Tan MA, Kogure N, Kitajima M, dela Cruz TEE, Takayama H, Nonato MG. 2010 A new isocoumarin compound from an endophytic fungus Guignardia sp. isolated from Pandanus amaryllifolius Roxb. ACGC Chemical Research Communications 24, 13-16.

Bungihan ME, Tan MA, Kitajima M, Kogure N, Franzblau SG, dela Cruz TEE, Takayama H, Nonato MG. 2011 - Bioactive metabolites of Diaporthe sp. P133, an endophytic fungus isolated from Pandanus amaryllifolius. Journal of Natural Medicines 65, 606-609.

Bungihan ME, Tan MA, Takayama H, dela Cruz TEE, Nonato MG. 2013a - A new macrolide isolated from the endophytic fungus Colletotrichum sp. Philippine Science Letters 6(1), 5773.

Bungihan ME, Nonato MG, Draeger S, Franzblau S, dela Cruz TEE. 2013b - Antimicrobial and antioxidant activities of fungal leaf endophytes associated with Pandanus amaryllifolius Roxb.. Philippine Science Letters 6 (2), 128-137.

Bussaban B, Lumyong S, Lumyong P, McKenzie EHC, Hyde KD. 2001 - Endophytic fungi from Amomum siamese. Canadian Journal of Microbiology 47(10), 943-948.

Clay K, Holah J. 1999 - Fungal endophytes symbiosis and plant diversity in successional fields. Science 285, 1742-1744.

Coronel RE. 1996 - Pili Nut, Canarium ovatum Engl. Promoting the conservation and use of underutilized and neglected crops. 6. Institute of Plant Genetics and Crop Plant Research, Gatersleben / International Plant Genetic Resources Institute, Rome, Italy.

Dagamac NHA, Sogono PG, Cabalfin RCB, Adducul ACY, dela Cruz TEE. 2008 - Fungal root endophytes from Musa spp. as biological control agents against the plant pathogen Fusarium oxysporum. Acta Manilana 56, 27-35.

de Errasti A, Carmaran CC, Novas MV. 2010 - Diversity and significance of fungal endophytes from living stems of naturalized trees from Argentina. Fungal Diversity 41(1), 29-40.

Firakova S, Sturdikova M, Muckova M. 2007 - Bioactive secondary metabolites produced by microorganisms associated with plants. Biologia 62(3), 251-257.

Gamboa MA, Bayman P. 2001 - Communities of endophytic fungi in leaves of a tropical timber tree (Guarea guidonia: Meliaceae). Biotropica 33(2), 352-360.

Gazis R, Chaverri P. 2010 - Diversity of fungal endophytes in leaves and stems of wild rubber trees (Hevea brasiliensis) in Peru. Fungal Ecology 3(3), 240-254.

Hallmann J, Sikora RA. 1996 - Toxicity of fungal endophytic secondary metabolites to plant parasitic nematodes and soil borne plant pathogenic fungi. European Journal of Plant Pathology 102, 155-162. 
Hipol RM. 2012 - Molecular identification and phylogenetic affinity of two growth promoting fungal endophytes of sweet potato (Ipomea batatas (L.) Lam.) from Baguio City, Philippines. Electronic Journal of Biology 8(3), 57-61.

Huang WY, Cai YZ, Hyde KD, Corke H, Sun M. 2008 - Biodiversity of endophytic fungi associated with 29 traditional Chinese medicinal plants. Fungal Diversity 33, 61-75.

Huang WY, Cai YZ, Surveswaran S, Hyde KD, Corke H, Sun M. 2009 - Molecular phylogenetic identification of endophytic fungi isolated from three Artemisia species. Fungal Diversity $36,69-88$.

Hyde KD, Soytong K. 2008 - The fungal endophyte dilemma. Fungal Diversity 33, 163-173.

Omacini M, Chaneton EJ, Ghersa CM, Muller CB. 2001 - Symbiotic fungal endophytes control insect host-parasite interaction webs. Nature 409, 78-81.

Petrini O. 1986 - Taxonomy of endophytic fungi of aerial plant tissues. In: Microbiology of the phyllosphere Fokkema NJ and van den Huevel J eds. Cambridge University Press, Cambridge.

Photita W, Lumyong S, Lumyong P, Hyde KD. 2001 - Endophytic fungi of wild banana (Musa acuminata) at Doi Suthep Pui National Park, Thailand. Mycological Research 105(12), 1508-1513.

Quinto E, Santos M. 2005 - Microbiology. In: A guidebook to plant screening: phytochemical and biological Guevara BQ ed. University of Santo Tomas Publishing House, Manila.

Rakotoniriana EF, Munaut F, Decock C, Randriamampionona D, Andriambololoniaina M, Rakotomalala T, Rakotonirina EJ, Rabemanantsoa C, Cheuk K, Ratsimamanga SU, Mahillon J, El-Jaziri M, Quetin-Leclercq J, Corbisier AM. 2008 - Endophytic fungi from leaves of Centella asiatica: occurrence and potential interactions within leaves. Antonie van Leeuwenhoek 93(1-2), 27-36.

Selim KA, El-Beih AA, Abd El-Rahman TM, El-Diwany AI. 2011 - Biodiversity and antimicrobial activity of endophytes associated with Egyptian medicinal plants. Mycosphere 2(6), 669-678.

Solis MJL, Yurkov A, dela Cruz TE, Unterseher M. 2014 - Leaf-inhabiting endophytic yeasts are abundant but unevenly distributed in three Ficus species from botanical garden greenhouses in Germany. Mycological Progress 14, 1019, DOI 10.1007/s11557-014-1019-6.

Strobel G, Daisy B. 2003 - Bioprospecting for microbial endophytes and their natural products. Microbiology and Molecular Biology Reviews 67(4), 491-502.

Sun X, Guo LD. 2012 - Endophytic fungal diversity: review of traditional and molecular techniques. Mycology: An International Journal on Fungal Biology 3(1), 65-76.

Tao G, Liu Z, Sun B, Zhu Y, Cai L, Liu X. 2012 - Occurrence and diversity of endophytic fungi in Bletilla ochracea (Orchidaceae) in Guizhou, China. African Journal of Microbiology Research 6(12), 2859-2868.

Torres JMO, dela Cruz TEE. 2013 - Production of xylanases by mangrove fungi from the Philippines and their application in enzymatic pretreatment of recycled paper pulps. World Journal of Microbiology and Biotechnology 29(4), 645-655.

Verma VC, Gond SK, Kumar A, Kharwar RN, Strobel G. 2007 - The endophytic mycoflora of bark, leaf, and stem tissues of Azadirachta indica A. Juss (Neem) from Varanasi (India). Microbial Ecology 54(1), 119-125.

www.conservation.org - 2007. 